\section{BUSINESS MODEL YOU SEBAGAI ALAT MEMULAI USAHA}

Christianus Yudi Prasetyo SE,M.Ak Program Studi Akuntansi

Universitas Pembangunan Jaya

Email : yudi.prasetyo@upj.ac.id

\begin{abstract}
Abstrak
Devaluasi mata uang Yuan oleh Pemerintah Tiongkok memberikan efek yang besar bagi perekonomian dunia, khususnya Indonesia. Efeknya banyak perusahaan-perusahaan nasional maupun multinasional yang melakukan PHK terhadap karyawankaryawannya. Hal ini menyebabkan banyaknya pengangguran di Indonesia yang apabila tidak terserap akan menyebabkan melambatnya pertumbuhan ekonomi.

Karyawan yang terkena PHK bisa memilih mencari pekerjaan lain atau menciptakan lapangan kerja sendiri dengan berwirausaha (entrepreneurship). Dapat dimulai dengan usaha mikro, kecil, dan menengah (UMKM) karena pemerintah banyak memberikan program-program agar UMKM ini dapat tumbuh pesat yang akhirnya akan menciptakan banyak lapangan pekerjaan.

Business Model You (BMU) adalah salah satu alat yang dapat digunakan untuk memulai usaha tersebut, walaupun tidak ada yang bisa menjamin usaha tersebut akan berhasil. Diperlukan faktor lain agar usaha tersebut dapat berhasil, seperti integritas dan etika berbisnis.
\end{abstract}

Kata kunci : PHK, wirausaha, business model you

\title{
Abstract
}

Devaluation of Yuan currency by the Chinese Government gives a great effect on the world economy, especially Indonesia. The effect is many of national and multinational companies doing layoffs of their employees. This causes the number of unemployed in Indonesia which, if not absorbed will lead to slowing down the economic growth.

The employees affected by layoffs can choose to find another job or create their own jobs with entrepreneurship. It can be initiated by micro, small, and medium enterprises (SMEs) as the government provides many programs so that SMEs can grow rapidly which eventually will create many new jobs.

Business Model You (BMU) is one tool that can be used to start the business, although no one can guarantee it will succeed. Another factor is required so that these business can be successful, such as integrity and business ethics.

Keyword : layoff, entrepreneurship, business model you 


\section{PENDAHULUAN}

Pada bulan Agustus 2015, Pemerintah Tiongkok mengumumkan melakukan devaluasi mata uang Yuan. Hal ini berpengaruh terhadap dunia termasuk Indonesia. Pengaruhnya juga dirasakan oleh perusahaan-perusahaan di Indonesia. Perusahaan-perusahaan di Indonesia mulai melakukan PHK terhadap karyawankaryawannya. Efek PHK ini secara psikologis sangat dalam. Yang langsung terbesit adalah bagaimana memenuhi kebutuhan sehari-hari? Lalu apa yang bisa dilakukan oleh karyawan setelah di PHK? Ada beberapa pilihan yang bisa dilakukan.

Pertama, mereka bisa mencari pekerjaan baru. Namun seperti kita ketahui untuk mencari pekerjaan baru tidaklah semudah membalikkan telapak tangan. Walaupun sepertinya banyak lowongan pekerjaan yang tersedia tetapi kenyataannya cukup sulit untuk mendapat pekerjaan. Jangankan mendapat pekerjaan, mendapat panggilan untuk tes saja belum tentu ada. Berbeda halnya jika kita mempunyai koneksi, mendapatkan pekerjaan akan lebih mudah.

Pilihan kedua adalah berwirausaha (Entrepreneurship). Berwirausaha tidak harus dengan skala yang besar tetapi bisa dimulai dari skala kecil. Di Indonesia dikenal dengan Usaha Mikro, Kecil dan Menengah (UMKM). Untuk sektor UMKM ini, Pemerintah sudah memberikan programprogram agar UMKM dapat tumbuh pesat yang akhirnya dapat memberikan lebih banyak lapangan pekerjaan. Menurut Kepala BPS Suryamin (dalam wawancara dengan BBC Indonesia) UMKM saat ini jumlahnya mencapai 3,5 juta usaha dan tumbuh 5,79\% pertahun. Pemerintah juga sedang "menggarap" agar bisa menampung lebih banyak pekerja, dengan cara mempermudah izin dan pengembangan usaha.

Entrepreneurship bertujuan untuk membuka lapangan kerja sendiri, sehingga angkatan kerja dapat terserap yang akhirnya mengurangi angka pengangguran, terlebih lagi saat ini kita telah memasuki Masyarakat Ekonomi ASEAN, yang salah satunya adalah bebasnya aliran tenaga kerja, maka persaingan kedepannya dapat dipastikan akan semakin berat.

Dalam tulisan ini akan dibahas hal-hal apa saja yang perlu diketahui dalam memulai suatu usaha agar memiliki penghasilan yang dapat digunakan untuk mencukupi kebutuhan hidup sehari-hari.

\section{TINJAUAN TEORITIS}

\subsection{Kewirausahaan}

Kewirausahaan dilihat dapat memberi- kan dampak positif terhadap ekonomi dunia (Ireland \& Webb, 2007). Kewirausahaan tidak hanya menghasilkan produk/jasa yang 
baru dan inovatif untuk pelanggan dan perusahaan (Covin \& Miles, 1999), tetapi juga menciptakan pekerjaan baru dan merevitalisasi ekonomi (Birley, 1986). Sekarang ini, dapat kita lihat pertumbuhan yang cepat dari kewirausahaan dan program bisnis kecil di perguruan tinggi di seluruh dunia (Solomon, 2006).

Membina kewirausahaan telah menjadi prioritas tertinggi dalam kebijakan publik (Luthje dan Franke, 2003). Dalam pandangan itu, pendidikan kewirausahaan dalam lembaga pendidikan yang lebih tinggi dipromosikan di kedua negara-negara industri dan industrialisasi sebagai mekanisme untuk mendidik dan mengembangkan siswa untuk karir kewirausahaan dan melengkapi mereka dengan keterampilan dan kompetensi yang diperlukan untuk bersaing dalam pasar global. (Nabi dan Holden, 2008)

Seseorang yang memiliki, menjalankan, dan mengambil resiko dalam suatu bisnis dinamakan wiraswasta (Green, 2012). Macam-macam latar belakang yang melandasi seseorang untuk menjadi wiraswasta adalah :

1. Karena berasal dari keluarga pengusaha.

2. Karena ingin jam kerja yang fleksibel

3. Karena mempunyai mimpi tertentu
4. Karena keadaan.

Jadi ada perbedaan besar antara wiraswasta dengan karyawan. Karyawan masih bekerja dengan orang lain, dan dia tidak terkena dampak langsung dari keputusan yang dia buat. Contoh: seorang manajer pemasaran membuat suatu strategi pemasaran yang baik sehingga menghasilkan penjualan yang tinggi. Dampaknya, manajer tersebut akan dipuji oleh pemilik perusahaan dan akan diberikan kenaikan gaji atau komisi.

\subsection{Business Model You}

Business Model You (BMU) berasal dari Business Model Canvas (BMC) namun dilihat dari perspektif yang berbeda. BMC dilihat dari sisi perusahaan, sedangkan BMU dilihat dari sisi individunya. Jika BMC melihat potensi yang dimiliki oleh perusahaan, BMU melihat potensi yang dimiliki oleh masing-masing individu. Untuk individu yang ingin memulai berwirausaha, lebih tepat menggunakan BMU. Ada 9 komponen dalam BMU yang dapat digunakan untuk memulai suatu usaha, yaitu : sumber daya, kegiatan, pelanggan, nilai yang diberikan, jaringan, hubungan dengan pelanggan, mitra, biaya, dan pendapatan.

\section{PEMBAHASAN}

\subsection{Bagaimana Membuat Bmu}


Berdasarkan 9 komponen yang telah disebutkan di atas, kita akan membahas masing-masing komponen.

\section{Sumber daya.}

Ada 2 (dua) pertanyaan yang dapat membantu kita untuk menjabarkan komponen ini, yaitu :

Siapakah anda? Terdiri dari beberapa aspek:

Minat. Hal-hal apa yang anda gemari dan senangi, karena pasti akan lebih baik mengerjakan sesuatu yang memang kita senangi/gemari. Mulailah membuat daftar tentang hal-hal yang anda minati, contoh : berlari, bersepeda, membaca, dll.

Keterampilan. Kebisaan kita melakukan sesuatu dengan adanya latihan dan belajar, contoh : memainkan alat musik, mengendarai kendaraan, perawatan, analisa keuangan, dll.

Kemampuan. Kebisaan kita melakukan sesuatu tanpa bersusah payah, karena anugrah yang diberikan Tuhan kepada kita, contoh : bernyanyi, fasilitator kelompok, dll

Kepribadian. Kita harus mengetahui kepribadian kita sendiri, apakah kita orang yang periang, pendiam, terbuka, tertutup, dll.

Apa yang anda miliki? Terdiri dari :
Tidak berwujud. Dapat diisi dengan pengalaman apa yang anda miliki. Bisa pengalaman dari pekerjaan-pekerjaan sebelumnya ataupun pengalaman lainnya di luar pekerjaan, seperti : terlibat langsung dalam membuat suatu acara besar, mengkoordinir acara jalan-jalan, dll. Kalau tidak punya pengalaman, pengetahuan dapat juga dimasukkan, misalnya : pernah mengikuti pelatihan, tahu banyak tentang seluk beluk motor tua karena ikut dalam organisasi pencinta motor tua, dll.

Berwujud.Dapat berupa kendaraan bermotor, tabungan, konstum, peralatan khusus, dll.

Kegiatan. Pertanyaan yang dapat membantu adalah apa yang pernah anda lakukan?. Jabarkanlah semua kegiatan yang pernah dilakukan pada pekerjaan sebelumnya. Setelah itu pilihlah kegiatan yang pentingpenting saja, dalam kata lain kegiatan yang membedakan kita dengan orang lain.

Pelanggan. Dalam memulai suatu usaha, mungkin kita akan bingung mencari siapa yang bisa kita jadikan pelanggan. Ada pertanyaan yang bisa membantu, yaitu siapa yang anda bantu? Mulailah membuat daftar orang-orang yang pernah bekerja dengan anda, yang bergantung kepada anda untuk menyelesaikan pekerjaan mereka, termasuk di dalamnya adalah bos anda ataupun supervisor anda. Dapat juga anda masukkan 
nama-nama orang dari departemen lain yang memperoleh keuntungan dari pekerjaan anda. Berikutnya, pikirkan sejenak apakah ada pihak-pihak dari luar perusahaan yang terkait dengan anda? Kalau ada, mereka bisa anda anggap sebagai pelanggan anda.

Nilai yang diberikan. Bagaimana anda membantu orang lain menyelesaikan pekerjaan mereka. Bila usaha kita di bidang jasa, tentunya nilai yang diharapkan adalah pelayanan yang ramah, responsif, dapat memberikan solusi, dll.

\section{Jaringan.}

Bagian ini lebih mengarah pada marketing. Pertanyaan-pertanyaan yang dapat membantu adalah :

Bagaimana pelanggan potensial mengetahui produk/jasa anda? Macam-macam cara yang dapat kita tempuh, antara lain :

Mulut ke mulut. Merupakan cara yang paling mudah, murah dan cukup ampuh. Apabila orang suka/puas dengan produk/jasa kita, orang tersebut akan merekomendasikan produk/jasa kita ke orang lain, begitu seterusnya hingga akhirnya produk kita dikenal secara luas.

Membuat iklan. Butuh biaya untuk merealisasikannya, namun cukup efektif. Contohnya saja bila kita memasang iklan di surat kabar nasional, berarti informasi tentang produk kita juga tersebar secara nasional.

Website. Media yang paling luas jangkauannya, karena tidak terbatas wilayah dan waktu, selama bisa terhubung ke internet maka produk kita bisa dilihat orang di negara manapun dan kapanpun, apalagi kalau website dibuat dengan Bahasa Inggris. Pembuatan website pun sekarang lebih mudah dan murah karena banyak yang menyediakan template website secara gratis.

Bagaimana pelanggan akhirnya memutuskan untuk menggunakan produk/jasa anda?

Jika produk/jasa merupakan suatu produk/jasa yang sudah umum, maka anda harus memberikan sesuatu yang berbeda. Contoh : harga yang lebih murah, kualitas produk yang lebih baik, dll.

Bagaimana mereka membeli produk/jasa anda?

Anda harus menginformasikan kontak anda, apakah nomor telefon, alamat email, alamat website, media sosial (facebook, twitter, Instagram,dll), agar pelanggan dapat membeli produk/jasa anda.

Bagaimana anda mengirimkan produk/jasa anda?

Kalau anda mempunyai kendaraan bermotor, bisa menjadi pilihan untuk 
mengantar produk anda. Pilihan lain adalah menggunakan jasa pengiriman yang saat ini sudah cukup banyak (kantor pos, JNE, TIKI, dll).

Bagaimana memastikan pelanggan anda senang dengan produk/jasa anda?

Pertanyaan inilah yang kadang terlupakan oleh pelaku usaha, terutama yang usahanya berupa produk. Hal ini sulit dilakukan apabila kita menjual produk ke pelanggan secara langsung, karena sulit untuk meminta identitas pembeli (nama, alamat, nomor telefon). Jika pelanggan kita masih sedikit dan masih kita kenal tidak menjadi masalah, tetapi jika pelanggan kita semakin banyak dan bukan orang yang tidak kita kenal maka akan sulit mengaplikasikannya. Lain halnya apabila menjual produk secara online. Usaha online akan lebih mudah karena kita dapat memberikan suatu "tempat" khusus dimana pembeli dapat memberikan komentar atas barang yang telah dibelinya.

\section{Hubungan dengan pelanggan.}

Bagaimana anda berinteraksi dengan pelanggan anda?

Personal. Bertemu secara langsung dengan pelanggan.

Kelebihannya adalah lebih mudah untuk menerangkan produk/jasa yang anda jual dan lebih mudah membujuk, sehingga pelanggan tertarik untuk membeli.

Kekurangannya adalah membutuhkan waktu dan tenaga yang lebih untuk menemui pelanggan satu per satu.

Hands off. Lebih mengandalkan email, website, media sosial.

Kelebihannya adalah kita bisa melakukannya dimana saja dan kapan saja selama terhubung dengan jaringan internet.

Kekurangannya adalah kita tidak bisa menjelaskan produk/jasa yang kita tawarkan secara lugas dan tidak bisa membujuk pelanggan, sehingga kemungkinan pelanggan tertarik untuk membeli lebih kecil dibandingkan kita bertemu langsung dengan pelanggan.

Transaksi apa yang anda pilih?

1. Transaksi tunggal. Anda hanya menjual produk saja, tidak disertai after sales service.

2. Transaksi berkelanjutan. Ada after sales service. Anda tidak hanya menjual produk, tapi anda memberikan layanan perbaikan dan menyediakan spare part kalau produk yang anda jual rusak. Akan lebih baik lagi jika anda bisa memberikan jaminan pengembalian barang atau 
perbaikan gratis selama kurun waktu tertentu.

\section{Mitra.}

Yang dimaksud dengan mitra disini adalah orang-orang yang bisa membantu anda. Mitra dapat memberikan motivasi, masukan, dan nasehat kepada anda sehingga usaha anda dapat berkembang. Mitra dapat diambil dari teman kerja dari pekerjaan sebelumnya, keluarga, teman, ataupun tenaga professional.

\section{Pendapatan.}

Buatlah daftar tentang sumber-sumber pendapatan anda. Pada awalnya mungkin pendapatan anda hanya dari hasil produk/jasa yang anda jual, tetapi sumber pendapatan anda nantinya bisa berkemang seiring dengan berkembangnya usaha anda, misalnya : dari sponsor, atau dari royalti kalau usaha anda sudah menjadi franchise, dll.

\section{Biaya}

Yang dimaksud biaya disini adalah semua yang anda berikan pada usaha anda, seperti : waktu, tenaga, uang.

Biaya dikelompokkan menjadi 2 (dua), yaitu
Berwujud, seperti : pelatihan, transportasi, kendaraan, peralatan, kostum khusus, telefon, internet, dll

Tidak berwujud, seperti : stres ataupun ketidakpuasan saat bekerja dengan mitra, komplain dari pelanggan, dll.

\section{KESIMPULAN}

Memang tidak ada yang bisa menjamin bahwa setiap usaha yang kita buat dan jalani akan berhasil, tetapi dengan menjabarkan 9 komponen yang ada di BMU setidaknya dapat membantu kita mengerti bagaimana usaha kita dapat berhasil (Clark, 2012, 22). Menurut Greene (2012,5-6), integritas dan etika bisnis merupakan hal yang penting dalam entrepreneurship. Seseorang yang memiliki etika bisnis akan menjaga hubungan baik dengan semua pihak yang berhubungan dengan kegiatan bisnis. Seseorang yang punya integritas, akan memiliki kekonsistenan dalam tindakan, nilai-nilai, prinsip-prinsip, ekspektasi, dan hasil.

\section{Daftar Pustaka}

1. Birley, S. (1986). The role of new firms, births, deaths, and job generation. Strategic Management Journal.

2. Clark, T., Alexander, O., \& Yves, P. (2012). Business Model You. John Wiley \& Sons, Inc. 
3. Covin, J. G. (1999). Corporate entrepreneurship and the pursuit of competitive. Entrepreneurship Theory and Practice.

4. Green, C. L. (2012). Entrepreneurship Ideas in Action. South-Western, Cengage Learning.

5. Hidayat, R. (t.thn.). bbc.com. Dipetik Februari 17, 2016, dari http://www.bbc.com/indonesia/berita_in donesia/2016/02/160216_indonesia_bur uh_phk

6. Ireland, R. D. (2007). A crossdisciplinary exploration of entrepreneurship. Journal of Management.

7. Luthje, C. a. (2003). The making of an entrepreneur: testing a model of entrepreneurial intention among engineering students at MIT. $R \& D$ Management.

8. Manurung, A. H. (t.thn.). Kompas Print. Dipetik Februari 15, 2016, dari http://print.kompas.com/baca/2015/09/2 7/Pengaruh-Devaluasi-Yuan

9. Melani, A. (t.thn.). liputan6.com. Dipetik Februari 15, 2016, dari http://bisnis.liputan6.com/read/2293121/ keuntungan-dan-kekurangan-devaluasiyuan-bagi-ri

10. Nabi, G. a. (2008). Graduate entrepreneurship: intentions, education and training. Education and Training. 